\section{Wilms's tumour-a correction and an apology}

Sir,

My faith in the flawlessness of British medical writing has been shattered by the repeated misspellings of Professor Wilms's name in the paper by Evans and Holzel (Archives 1973, 48, 645).

Not only was poor old Professor Wilms's name misspelt throughout the body of the paper, but even more disrespectful to his memory was the diligent effort on the part of someone to change the correct spelling of Wilms's surname to the incorrect one in all the references cited in which Wilms's name is given.

Please restore my faith in medical editing on your side of the Atlantic.

THOMAS E. CONE, JR. Associate Editor, Pediatrics, 300 Longwood Ave., Boston, Mass. 02115, U.S.A.

Dr. Cone is of course correct, and we apologize abjectly. We will try to do better in future, and to restore Dr. Cone's faith. Editors.

\section{Effect of fatty acids on bilirubin conjugation}

Sir,

We were interested in the article by $T$. Hargreaves (Archives, 1973) concerning the interaction between fatty acids and bilirubin conjugation in vitro. In an earlier study (Levillain et al., 1972) we showed similar results with unsaturated fatty acids but also some inhibition of conjugation with saturated fatty acids. The discrepancy between these results could be due not only to a different concentration in incubation milieu (we used approximately a concentration of $2 \mathrm{mmol} / \mathrm{l}$. for each saturated fatty acid), but essentially to a different relative concentration of fatty acid, bilirubin, and albumin. This possibility was tested in a recent study (Luzeau et al., 1973a).

We also found (Levillain et al., 1972; Luzeau et al., 1973a) a relation between the inhibitory effect of mother's milk samples on the glucuronyl transferase activity in vitro and their concentration of free fatty acids. Milk samples from mothers whose infants had a prolonged neonatal jaundice inhibited the enzyme activity and contained more free fatty acids than control samples. This difference cannot be detected in fresh milk samples but becomes obvious after storage, depending on duration and temperature conditions. An important liberation of fatty acids only takes place in pathological milks when they are kept at $+4{ }^{\circ} \mathrm{C}$ or $+20{ }^{\circ} \mathrm{C}$ while their in vitro inhibitory effect increases. Such liberation does not take place when the milk samples are preheated at $+56^{\circ} \mathrm{C}$ for 15 min immediately after the collection. The results obtained suggest the existence of an abnormal lipolytic activity in the milk of mothers whose infants have a prolonged jaundice. Lipoprotein lipase seems to be the enzyme responsible for the activity. These experimental data allowed us to feed 3 icteric infants with maternal milk after heating at $56{ }^{\circ} \mathrm{C}$ for $15 \mathrm{~min}: 3$ or 4 days later the jaundice had disappeared. A simplified method for detection of these inhibitory milk samples has been recently described using nile blue reaction (Luzeau et al., 1973b).

M. ODIÈVRE, P. LEVILLAIN, R. LUZEAU, and A. LEMONNIER Hôpital Parrot, 78 rue du Général-Leclerc, 94 Bicêtre, France.

\section{REFBRENCES}

Hargreaves, T. (1973). Effect of fatty acids on bilirubin conjugation. Archives of Disease in Childhood, 48, 446.

Levillain, P., Odièvre, M., Luzeau, R., and Lemonnier, A. (1972). Possibilités d'inhibition de la glucuroconjugaison de la bilirubine en fonction de la teneur en acides gras libres du lait maternel. Biochimica et Biophysica Acta, 264, 538.

Luzeau, R., Levillain, P., Odièvre, M., and Lemonnier, A. (1973a). Demonstration of a lipolytic activity in human milks that inhibit the glucuroconjugation of bilirubin. Biomedicin. (In the press.)

Luzeau, R., Levillain, P., Odièvre, M., and Lemonnier, A. (1973b). Dépistage des laits maternels inhibiteurs de la glucuroconjugaison de la bilirubine par une réaction colorée. Archives Francaises de Pédiatrie, 30 . (In the press.)

Dr. Hargreaves comments as follows:

The letter from Professor Odièvre and his colleagues emphasizes yet again the difficulties in elucidating the cause of breast milk jaundice (Arias et al., 1964; Hargreaves and Piper, 1971). The observed differences between the effects of fatty acids are probably due to the concentrations used. I used a maximum concentration of $1 \mathrm{mmol} / \mathrm{l}$. for the investigations of saturated fatty acids on bilirubin conjugation in rat liver slices (Archives, 1973, 48, 446) whereas Levillain et al. (1972) and Bevan and Holton (1972) used higher concentrations. In rat liver microsomes I found no inhibition of bilirubin conjugation by saturated fatty acids even at high concentrations. Bevan and Holton (1972) compared the effect of inhibitory breast milk and oleic acid on the bilirubin content of rat liver slices. They showed that the effect was similar except that high concentrations of 